\title{
高齢運転者の認知特性と実環境における不安全行動の関連性の検討*
}

\author{
小竹元基 ${ }^{* 1}$ ，木村健人 ${ }^{* 2}$ ，二瓶美里 ${ }^{* 1}$ ，鎌田 実 ${ }^{* 3}$
}

\section{Analysis on Relation between the Unsafe Driving Behavior in Actual Environment and the Cognitive Characteristics of Elderly Drivers}

\author{
Motoki SHINO*1 ${ }^{*}$ Taketo KIMURA, Misato NIHEI and Minoru KAMATA \\ ${ }^{* 1}$ The University of Tokyo Dept. of Mechanical Engineering \\ 7-3-1 Hongo, Bunkyo-ku, Tokyo, 113-8656 Japan
}

Traffic accidents involving elderly drivers are major concerns in Japan. Age-related decline in cognitive function is said to be one of the causes of these accidents, so it is important to propose driving support system considering cognitive ability to reduce these accidents. It is necessary to clarify the relation between cognitive ability and driving behavior of elderly drivers. We measured cognitive characteristics of elderly drivers and proposed a method to classify elderly drivers based on cognitive characteristics and examined the relation between cognitive ability and unsafe driving behavior.

Key Words : Cognitive Function, Elderly Drivers, Unsafe Behavior, Driving Ability

\section{1. はじめに}

近年，日本では高齢運転者による交通事故が問題となっている．国内の交通事故件数は全体としては減少傾向 にあるのに対し，高齢運転者の交通事故件数は増加している ${ }^{(1)}$.これら事故の要因としては，日本における高齢 化の進展や，加齢に伴う心身機能の低下などが挙げられる．しかし，とりわけ公共交通機関の整備が十分ではな い地方部在住の高齢者にとって, 自動車は依然重要な自立移動手段である現状を考えると, 高齢運転者の心身機 能の低下に応じた事故を防ぐための対策が重要となる.

自動車の運転は認知, 判断, 操作の繰り返しからなる．運転者が運転中に外界情報を知覚し，必要な情報を認 識する段階を認知といい，運転の過程においてこの認知特性が判断や操作に影響する．運転時に必要な認知に関 わる機能として従来から注目されている能力の一つとして有効視野があり, それは周辺視野のうち認知に寄与す る部分である. Owsley らは, 294 名の高齢運転者（56９0 歳）を対象として, 視感覚機能，有効視野，認知機能 検査, 目の健康状態といった特性と, これらの特性を測る実験前 5 年間と実験後 3 年間の交通事故回数の関係の 調查を行った結果，自動車事故回数を最もよく説明できるのは有効視野であり，また，40\%以上の有効視野縮小 が見られることと過去 5 年間の事故経験との間に高い相関が見られたと報告している(2).また， Myers らは 43 人 の高齢被験者（平均年齢 73 歳）に対し，有効視野の広さが路上走行テストの成績を単独で説明する変数である ${ }^{(3)}$ ことを示し,Cushman らは123名の被験者に対し有効視野を含む認知機能テストと路上走行テストを行った結果, 有効視野の選択的注意課題の成績が運転能力を最もよく説明する指標である(4)ことを示している. これらの従来 研究では，加齢により低下する認知能力である有効視野の特性が運転行動に影響することを示し，高齢者の運転 において重要な要素であることを述べている. しかし, 加齢により低下寸る各個人のどのような認知能力が, 事 故に結びつく可能性のあるどのような不安全な行動に影響するかを明らかにしていなく，個人差の大きい高齢者

* 原稿受付 2012 年 2 月 28 日

${ }^{*}$ 正員, 東京大学（干113-8656 東京都文京区本郷 7-3-1）

*2 東京大学

*3 正員, 東京大学高齢社会総合研究機構

E-mail: motoki@sl.t.u-tokyo.ac.jp 
を全体の傾向として捉えている.

本研究では，高齢者の運転における認知の過程に着目し，その認知特性と不安全行動の関係を明らかにするこ とを目的とする，そこで，日常的に自動車を運転している高齢者を対象に，実車を用いた運転行動記録から認知 に起因寸る不安全行動を整理し，各高齢運転者の認知特性の把握と分類を行い，その認知特性と実環境の運転に おける不安全行動の関連性を考察する.

\section{2. 本研究の位置づけ}

高齢者の運転は，防衛運転も含め，その人の生活，身体特性に依存する場合が多い，そのため，運転行動を把 握するには，何が原因でそのような行動を起こすかといった，身体特性を含む要因を把握することはとても重要 である．著者らは，同一の被験者に対して様々なデータを収集し，運転以外の背景要因に関するデータ(5)(6) とし て, 常時記録ドライブレコーダにより計測した日常生活における右折時の運転行動, 各高齢運転者の背景要因 (生 活，身体特性）の計測データを整理することにより，高齢運転者のタイプ分類を行ってきた ${ }^{(7)}$.また，一時停止 交差点進入時に必要な行動と高齢者の身体特性から情報支援システムを提案してきた ${ }^{(8)}$. それら先行研究では, 運転以外の特性と運転行動を関連づけることにより，タイプ分類や支援設計を行ってきたが，本研究では，高齢 者が行う認知, 判断, 操作の一連の運転過程において, 加齢に影響寸る認知特性と運転時の確認行動や操作行動 を把握することにより，認知が起因する不安全行動と高齢運転者の認知特性の関連性を捉える.

\section{3. 高齢者の実車運転に基づく不安全行動の整理}

運転は日常生活の一部であると考え，高齢者自身の車に常時用ドライブレコーダを搭載し，実験参加者には， 普段の生活において, 自由に走行させた. その運転行動データから日常移動の中で発生する不安全行動を抽出し, 認知に起因する不安全行動を整理する.

\section{$3 \cdot 1$ 実車を用いた運転行動記録}

日常の運転行動を記録するため，常時記録型ドライブレコーダ（ITS21 製）を用いた．計測状況は，外界環境 と運転者の行動を 6 台のカメラにより記録している．映像データの例を図 1 に示す．また車体挙動測定のために 加速度センサ，車両位置計測のために GPS センサを使用している．対象者は日常的に自動車を運転している高齢 者 4 名（平均年齢 78.5 歳, $\mathrm{SD}=3.32$ ） である. 表 1 に実験参加者の詳細を示す. 尚, 本実験は東京大学大学院工 学系研究科の倫理審查を受け承認されており, 実験参加者には実験内容を十分に説明し, インフォームドコンセ ントを得ている.

Table 1 Participants of driving behavior experiment

\begin{tabular}{|c|c|c|c|c|c|}
\hline Subject & Age/Sex & $\begin{array}{c}\text { Driving } \\
\text { experience } \\
\text { (year) }\end{array}$ & $\begin{array}{c}\text { Frequency of } \\
\text { driving (days } \\
\text { per week) }\end{array}$ & $\begin{array}{c}\text { Experimental } \\
\text { period (weeks) }\end{array}$ & $\begin{array}{c}\text { Recording time } \\
\text { (hours : minute) }\end{array}$ \\
\hline \hline E3 & 79/Male & 44 & $3-6$ & 3 & $11: 17$ \\
\hline E5 & $73 /$ Male & 47 & $3-6$ & 2 & $9: 47$ \\
\hline E12 & $79 /$ Male & 46 & $1-2$ & 2 & $9: 37$ \\
\hline E13 & $76 /$ Male & 50 & everyday & 4 & $11: 23$ \\
\hline
\end{tabular}

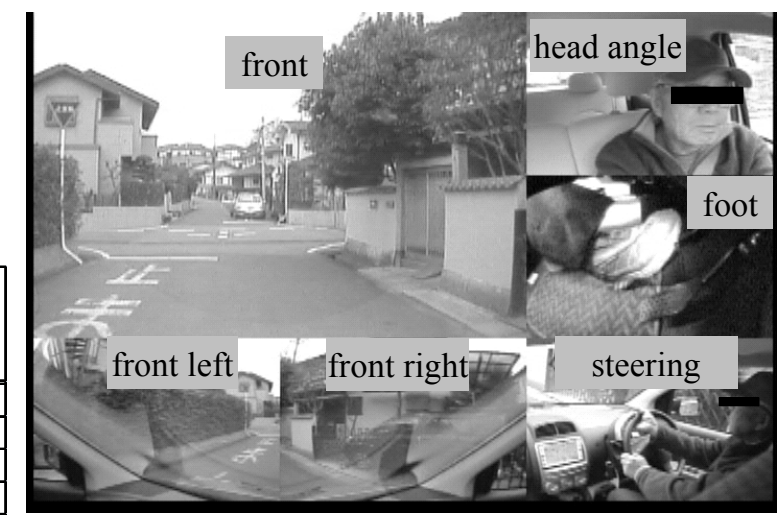

Fig. 1 Example of video data recorded by driving recorder

\section{$3 \cdot 2$ 不安全行動の事例}

$3 \cdot 1$ 節で示したドライブレコーダにより採取した運転行動データを分析し不安全行動の事例をまとめると, 確 認が不十分な状態での一時停止交差点への進入, 見通しの悪い住宅街走行時の急停止, 先行車の減速に気がつく 
のが遅れ，急停止する事例などが見られた．この事例は，交通事故統計 ${ }^{(9)}$ で示される高齢運転者の事故の特徵と 同様であり, 認知に影響する不安全な行動が多い. そこで, これら一つ一つの事例について不安全行動の発生要 因を検討したところ，交通環境の認知に関わる以下の 3 つの可能性を不安全行動の要因として考えた.

- 外界状況の見落とし

・特定の対象への注意の偏り

・対象物のもつ危険性の評価の不適

\section{$3 \cdot 3$ 認知に起因する不安全行動の発生過程}

$3 \cdot 2$ 節でえられた不安全行動の要因を抽出寸るため, 本研究ではドライバの運転行動過程を図 2 のように捉え 議論を進める. これは認知, 判断, 操作からなる自動車運転行動過程の認知の部分について, 既存研究 ${ }^{(10)}$ を基に より細かく段階に分けたものである．本研究における用語の定義を以下で説明する.

ハザード(Hazard)：事故可能性と関連性を持つ全てのものや事象

ハザード知覚 (Hazard Perception) : 交通環境の状況からハザードを知覚，認識する過程

リスク (Risk): 八ザードによる事故発生の期待值（事故の重大性と発生確率の組み合わせ）

リスク知覚(Risk Perception) : 知覚したハザードからリスクを見積もる過程

ドライバはまず交通環境からハザードを知覚，認識する．この過程をハザード知覚と呼ぶ．次に，認識した八 ザードから自身の運転能力や経験といった要素を加味してリスクを評価する．この過程をリスク知覚と呼ぶ。ド ライバは自身が評価したリスクに応じて次にとる行動を選択し (判断)，実行する (操作)。このような運転行動 過程を基に，高齢運転者の認知過程をハザード知覚とリスク知覚の両側面から捉える.

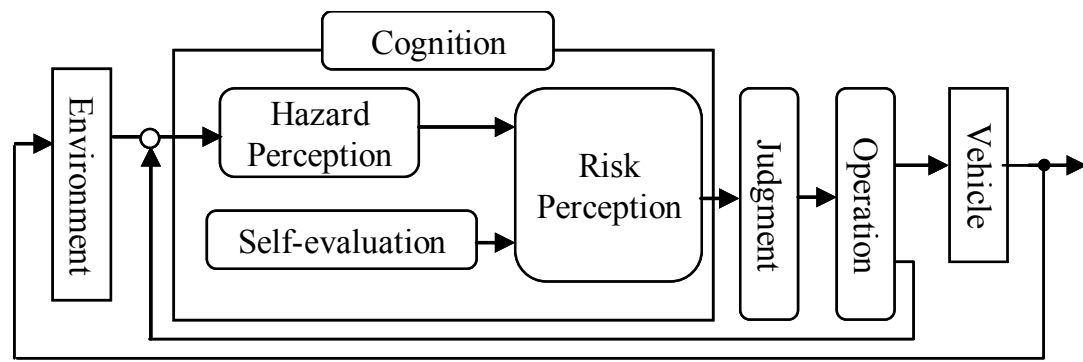

Fig. 2 The process of driving behavior

\section{3 -4 実環境における認知に起因する不安全行動}

\section{$3 \cdot 4 \cdot 1$ 実環境における走行シーンの選定条件}

認知に起因する不安全行動を整理するには，実環境における走行シーンを選定する必要がある，その条件とし て，まず同一条件で各高齢者間の比較を行えるシーンであることである．次に，本研究では各高齢者の認知特性 をハザード知覚とリスク知覚のそれらの能力で整理することを考えており，選定したシーンにおける不安全行動 が運転者のハザード知覚，もしくはリスク知覚のどちらか一方の能力の影響を支配的に受けると考えられるシー ンであることである.

通常時より大きな減速度での停止行動は, その他の要因による不安全行動とも結びついている可能性はあるも のの, ハザードとして知覚, 認識の必要性の高い対象の見落としが原因となり, その対象に遅れて気づいた結果, 急なブレーキ操作に至った事例を多く含むと考えられる，そのため，大きな減速度での停止の事例は，運転者の ハザード知覚能力の影響を大きく受けるシーンだと考えられる．また一時停止交差点通過時の行動は, 交差道路 に対し自車が非優先側であり, 死角に存在する潜在的なハザードに対して意図的に安全確認をする必要があるこ と, 客観的にみて事故を起こす危険が高いシーンであること ${ }^{(8)}$ から運転者のリスク知覚能力の影響を大きく受け るシーンだと考える. 
以上の条件から，本章ではハザード知覚能力の影響を強く受けると考えられる “通常時より大きな減速度での 停止時の行動”とリスク知覚能力の影響を強く受けると考えられる “一時停止交差点通過時の行動”を運転行動 記録から，映像と計測したデータをもとに抽出し，比較する.

\section{$3 \cdot 4 \cdot 2$ 減速度の大きな事例における不安全行動と認知特性との関連性}

記録された前後加速度を, $0.20 \mathrm{G}$ を閾值としてその值を超えてから下回るまでを 1 回のブレーキと考え, 1 回の ブレーキにおける加速度の最大值をそのブレーキによる減速度と定義する。また急減速については，実験参加者 間のブレーキのかけ方, 減速の仕方に大きな違いが無いことを確認した上で, サンプル数の確保と不安全でない 事例を除くための目安として $0.40 \mathrm{G}$ を閾值として採用した. 急減速となったブレーキの事例についてその要因と 考えられる認知特性の分析を行った結果を表 2 に示す。但し，表に示す “八ザード知覚能力と関連性のある急減 速事例”とは，不安全な急減速事例の内，リスク知覚能力と関連性のある事例を除く事例を示している.

E5 のハザード知覚に影響する事例として，4 件は先行車追従中, 先行車が緩やかな減速を行ったにもかかわら ずブレーキ開始が遅れ，急減速に至った場合であり，1件は交差点の信号が赤信号にかわったことに気づき，急 減速を行い，停止線を超えた状態で停止した事例である.この 5 件は前方の交通環境のハザードに対する知覚が 遅れ, 急減速を行った不安全な行動である. リスク知覚に影響する事例として，2 件は対向車の出現に対して急 減速になった事例である. DR の映像より, 見通しの悪い道路にも関わらず速度が高い状態でアクセルを踏み続 け，対向車の出現に対して急減速を行っている。これは見通しの悪い道路に対するリスクの評価が適当でなかっ たため，急減速を行った不安全な行動である. E13 のハザード知覚に影響する事例として，2件は E5 と同様に先 行車の緩やかな減速に気がつくことが遅れ，急減速を行っている．E5 と異なる運転行動としては，見通しの悪い 道路に近づいた際，アクセルペダルからブレーキペダルに踏み替えを行い，減速した後に見通しの悪い道路に近 づき，対向車に対して余裕をもって減速ができている．この見通しの悪い道路環境に対する行動は，E3，E12に おいても同様の行動が見られた.

Table 2 Relation between sudden braking maneuver cases and cognitive features

\begin{tabular}{|c|c|c|c|}
\hline Subject & $\begin{array}{c}\text { Number of sudden } \\
\text { braking maneuver } \\
\text { (more than } 0.40 \mathrm{G})\end{array}$ & $\begin{array}{c}\text { Relative to hazard } \\
\text { perception ability }\end{array}$ & $\begin{array}{c}\text { Relative to risk } \\
\text { perception ability }\end{array}$ \\
\hline E3 & 6 & 0 & 2 \\
\hline E5 & 9 & 5 & 0 \\
\hline E12 & 4 & 0 & 0 \\
\hline E13 & 18 & 3 & 0 \\
\hline
\end{tabular}

\section{$3 \cdot 4 \cdot 3$ 一時停止交差点における運転行動と認知特性との関連性}

一時停止交差点における停止, 安全確認の傾向を把握するため, 一時停止交差点における実験参加者の行動に ついて分析を行った。但し，交差道路に他車が走行している場合，運転行動に影響を与えることが考えられるた め，運転行動記録の映像から交差道路に他車が走行していないシーンを抽出し，統一して分析を行った. 表 3 に 一時停止交差点の通過回数を示す. E13 が最も一時停止交差点を通過する回数が多いことがわかる. 分析を行う 上で設定した行動の判断基準を以下に示す.

・一時停止の減速行動 : 映像において, 交差道路進入前に車体速度が明らかに 0 になったと確認できた場合を “停止”，それ以外の場合を“不停止”之判定する.

・確認行動の回数 : 運転者の足がブレーキペダル上にある状態で, 首振りおよび目線が左右にふれた回数

・確認時間 : 運転者が交差点に進入する際に左右どちらかに首振りもしくは目線で確認を開始し, 交差道路に 進入するためアクセルを踏み込むまでの時間.

一時停止交差点における停止状況を図 3 に示す. 全協力者において不停止の割合が高くなっている. 特に E5 において停止が 1 件も見られないことは，他の協力者に比べ一時停止交差点における平均的な進入速度が高い傾 向にあることを示し, リスク知覚能力の低下と関係する不安全な行動である. 次に, 一時停止交差点における平 
均確認時間を図 4 に示す。これを見ると，E5 の確認時間の平均值が他の協力者より短い．また，一時停止交差点 における平均確認回数を図 5 に示寸. E5 の確認回数が他と比べて少ないことがわかる. これらの結果は，一時停 止交差点といら交通環境に対して，リスクを低く見積もることによりおこる行動として考えられ，前節でえられ た表 2 で示すリスク知覚能力の傾向と関連性がある.

Table 3 Frequency of passing through the intersection with stop sign

\begin{tabular}{|c|c|c|c|c|}
\hline Subject(age) & E3(79) & E5(73) & E12(79) & E13(76) \\
\hline \hline $\begin{array}{c}\text { Frequency of passing through } \\
\text { the intersection [-] }\end{array}$ & 9 & 37 & 27 & 126 \\
\hline $\begin{array}{c}\text { Frequency of passing through } \\
\text { the intersection without the } \\
\text { vehicle crossing the } \\
\text { intersection [-] }\end{array}$ & 8 & 28 & 19 & 93 \\
\hline
\end{tabular}

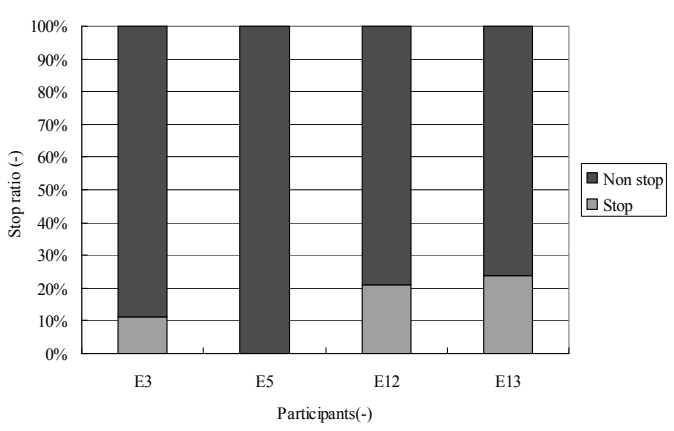

Fig. 3 Stop status at intersection with stop sign

IS.D.

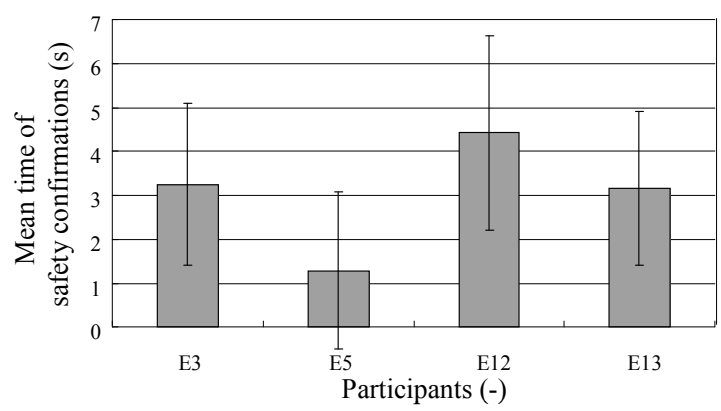

Fig. 4 Average time of confirmation

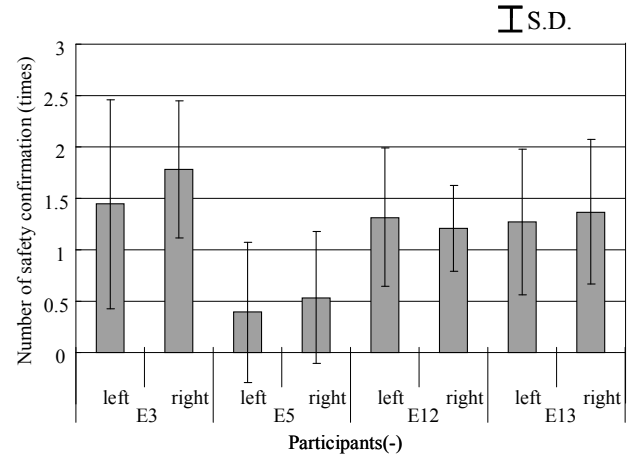

Fig. 5 The average number of confirmation

\section{$3 \cdot 4 \cdot 4$ 分析結果のまとめ}

運転行動過程に基づく実環境における運転行動データによる分析結果より，高齢運転者の認知に起因する不安 全行動の発生過程として, 次の 2 つのパターンがあげられる.

・ ハザードの見落とし，または複数のハザードの同時処理における誤り（ハザード知覚能力の低下）

・リスクの見積りの誤り（リスク知覚能力の低下）

「ハザードの見落とし」とは，走行する交通環境の中から知覚すべき，ないしは認識すべきハザードを取りこぼ し，その状況において不安全な行動を選択してしまうパターンである. 一方，「リスクの見積りの誤り」とは，知 覚したハザードの持つリスクを自己評価に比して過小に見積もってしまうことにより，不安全な行動を行うパタ ーンである.

\section{4. 高齢運転者の認知特性の把握実験}

3 章で整理した認知特性に起因する不安全行動を考える上で，あるハザードが存在する交通環境においてドラ イバがとった不安全な行動が，八ザードの知覚，認識を詋ったことによるものなのか，認識したハザードに対す るリスク評価の誤りによるものなのかを区別することは難しい，高齢者の不安全行動を抑制する上で，きちんと 特性により分類することは難しいが，不安全な行動の要因は支援形態を左右する重要な要素と考えられる苜えため, それらの影響を独立して評価することが重要だと考えた，そこで本研究では，既存研究を参考に，運転者のもつ ハザード知覚, リスク知覚の特性を独立して把握する実験を考案し, 高齢運転者を対象とした把握実験を行う. また，各高齢者間で統一した条件での実験が必要となるため，ドライビングシミュレータを用いた，尚，本実験 は東京大学大学院工学系研究科の倫理審查を受け承認されている. 実験参加者には研究内容を説明し, インフォ ームドコンセントをえた. 


\section{$4 \cdot 1$ 運転行動過程における高齢者の認知特性}

運転行動過程における認知は，運転者の内的な過程であるため，その把握には走行する交通環境からの入力に 対する運転者の出力（行動）から推測する方法をとる. 具体的には, タスク遂行中に見える範囲及び注意を払う 能力の $2 つ の$ 側面に焦点をあて，有効視野と複数の対象に同時に注意を払う能力（以下，分割的注意能力）を八 ザード知覚特性として把握する．また，リスク知覚特性を運転者がハザードのもつリスクを見積る能力と捉え， その能力はドライバが内的にもつ経験，知識に大きく影響すると考えられる，そこで，走行する交通環境に対し て運転者が情報をとる行動にそれらの影響を含むとし, その行動からリスク知覚の評価を行う。しかし, リスク 知覚特性はハザード知覚の過程からの出力を入力とするため, その特性がハザード知覚能力に依存してしまう.

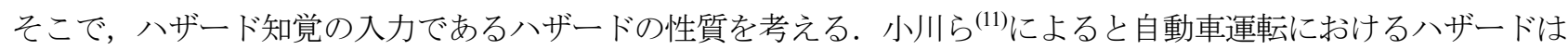
以下の 3 つに分類される.

・一般的なハザード : 顕在化したハザード（対向車，カーブなど）

・潜在的なハザード : 死角からの出現が予測されるハザード（死角のある交差点など）

・行動予測が必要なハザード : 目に見える他者のうち，次なる行動に危険が予測されるハザード（道路を横断し ようとしている自転車など）

そこで，ハザード知覚能力の影響を受けずにリスク知覚特性を評価可能な，運転者の“潜在的八ザード”に対 するリスク知覚特性に注目し，評価を行う.

\section{$4 \cdot 2$ 対象者}

日常的に自動車を運転している高齢者 14 名（平均年齢 77.4 歳，SD=5.56）に対し実験を実施した. 表 4 に実車 による運転行動記録を含む実験参加者の詳細を示す．高齢者の中には，認知症等の病的な要因により認知機能が 劣ることも考えられるため，参加者の基礎的な認知機能を把握することは重要である．そこで，MMSE

(Mini-Mental State Examination) を用いることにより , 認知症者を区分することにした. 参加者の平均得点は 29.1 （SD=1.59）で，全員著しい認知機能の低下は見られなかった．また，運転行動に関するアンケートから，実験 参加者の多くは買い物や通院，送迎のためといった目的で日常的に自動車を運転していることがわかっている. 本研究では，上記参加者 14 名という限られた属性における認知特性の把握を行う.

Table 4 Participants of experiment

\begin{tabular}{|c|c|c|c|}
\hline Subject & Age/Sex & $\begin{array}{c}\text { Driving } \\
\text { experience }\end{array}$ & $\begin{array}{c}\text { Frequency of driving } \\
\text { (days per week) }\end{array}$ \\
\hline \hline E1 & $84 /$ Male & 16 & $3-6$ \\
\hline E2 & $81 /$ Male & 31 & $1-2$ \\
\hline E3 & $79 /$ Male & 44 & $3-6$ \\
\hline E4 & $71 /$ Male & 52 & every day \\
\hline E5 & $73 /$ Male & 47 & $3-6$ \\
\hline E6 & $70 /$ Male & 40 & every day \\
\hline E7 & $74 /$ Male & 47 & $3-6$ \\
\hline E9 & $71 /$ Male & 50 & $1-2$ \\
\hline E10 & $84 /$ Male & 50 & $3-6$ \\
\hline E11 & $79 /$ Female & 41 & every day \\
\hline E12 & $79 /$ Male & 46 & $1-2$ \\
\hline E13 & $76 /$ Male & 50 & every day \\
\hline E14 & $88 /$ Male & 46 & every day \\
\hline E15 & $74 /$ Male & 36 & $1-2$ \\
\hline
\end{tabular}

\section{$4 \cdot 3$ 高齢運転者の認知特性の把握方法}

\section{$4 \cdot 3 \cdot 1$ ハザード知覚特性の把握方法}

- 運転時有効視野能力測定 : 運転という一連の過程における有効視野を測定するため, 右左折, 直進といった道 
路上を走行することを前提に，ドライビングシミュレータ（以下 DS）による運転時の有効視野計測を行った．走 行環境は，八ザード知覚特性のみを把握することを考え，八ザードの性質を考慮した．具体的には，道路上に道 路幅と道路曲率が運転者から認識しや寸いように図 6 に示寸白線，センターライン，樹木をおき，潜在的なハザ ード (建物等の死角) や行動予測が必要なハザード (歩行者, 自転車, 対向車等) は存在しない走行環境とした. タスクは，画角 $135^{\circ}$ のターンテーブル付 DS において運転操作と並行して，図 6(a)に示すように，DS 上で計算 された車両挙動，位置データから画面上にランダム的に出現する “×” 印（以下，視標）に対して，知覚の可否 を声で応答する課題である．評価は，視標の総反応数を視標の総出現数（計 152 個）で除した視標検出率によっ て行った．また，“メ”印の位置ごとの視標検出率を算出することが可能であるため，各被験者の運転時の有効 視野の広さ, 有効視野狭窄の方向特性の算出が可能となる.

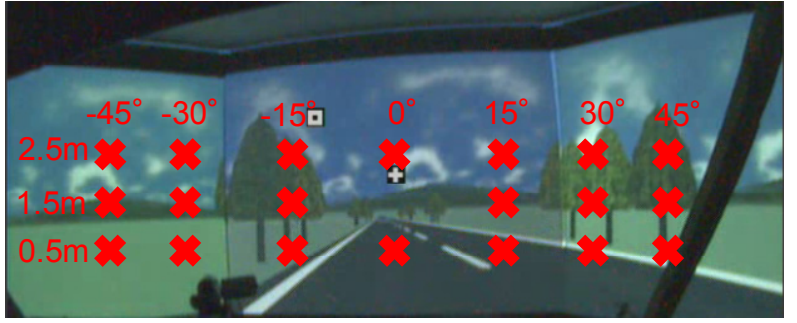

(a) Useful view test while driving

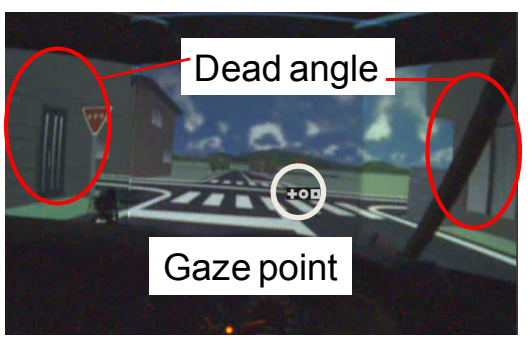

(b) Risk perception test while driving

Fig. 6 Recognition characteristics test while driving

・分割的注意能力測定 : 木村ら ${ }^{(13)}$ の計測方法を参考に, 図 7 に示すようなディスプレイ中央に表示される数字を 読み上げる課題（中心視課題）と，画面中央を注視するよう指示され，その周辺の 8 方向，異なる偏心度

$\left(4,8,12,16,20,24^{\circ}\right)$ のいずれかの位置にランダムに 1 つ出現する輝度変化刺激に対して, 実験参加者が手元のボ タンで反応する課題 (周辺視課題), 中心視課題と周辺視課題を同時に遂行する課題（二重課題）を行い，周辺刺 激（各課題計 48 回提示）に対する二重課題時と周辺視課題時の反応時間に有意な差が見られるかにより，その能 力の低下を評価した.
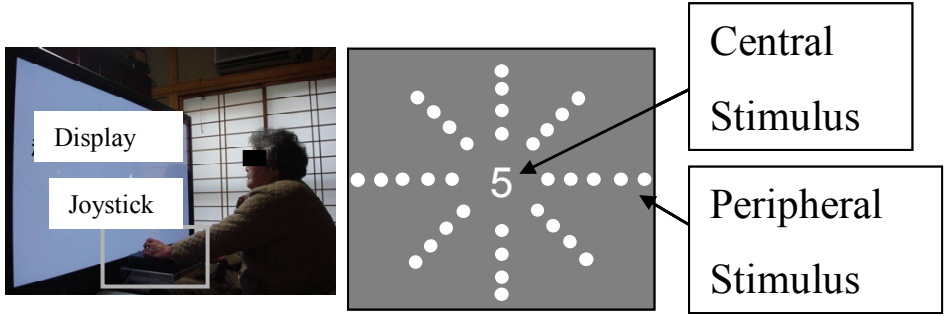

Fig. 7 Divided attention test

\section{$4 \cdot 3 \cdot 2$ リスク知覚特性の把握方法}

建物や標識，対向車や歩行者等が存在する市街地コースをDS 上に再現し，走行実験を実施した．実験参加者 には交通規則に従い普段通りの運転を行う様, 教示した. その上で, 図 6(b)に示すような死角が存在するシーン における運転者の行動を観察する事でリスク知覚能力の把握を行った. 具体的には死角が存在するシーンにおけ る行動として, 以下の 2 つに注目した.

・無信号交差点直進時における左右確認行動と減速（または低速走行）行動

- 一時停止交差点における左右確認行動

今回は $20 \mathrm{~km} / \mathrm{h}$ 以下での交差点進入時の走行を低速走行, 交差点手前 $100 \mathrm{~m}$ の区間で $5 \mathrm{~km} / \mathrm{h}$ 以上の速度低下を減速 行動として扱い，減速した場合でも交差点確認前に加速した場合は減速なしとして扱った．走行するコースにつ いては, 実験者が交差点毎に直進か右左折かを参加者に指示することで, 交差点の存在を参加者に伝えた. また, 運転中の視線行動を記録するため, アイカメラ（nac 社製 EMR-9）を用い，上記交通シーンにおける減速行動， 確認行動を行った試行数を集計し, リスク知覚能力の評価を試みた. 


\section{5. 実験結果に基づく高齢運転者の認知特性の整理}

\section{$5 \cdot 1$ ハザード知覚特性把握実験の結果}

運転時の有効視野測定結果として，視標検出率の結果を図 8 に示寸，尚，参加者全体の検出率の平均は 0.496 $(\mathrm{SD}=0.104)$ となった．また，本論文では，視標検出率が低い被験者の特性把握を行うことを目的としているた め，視標検出率が低い被験者 E1，E5，E11，E13，E14，E15 における視標出現箇所による検出率の違いを図 9 に示 す. また，その比較対象として，視標検出率の高い E7, E12 の結果も示した. 出現箇所は，左右 $-45^{\circ}$ から $45^{\circ}$, DS の奥行き距離として，0.5m，1.5m，2.5mの計 20 箇所について，各実験参加者の検出率の違いにより 3 段階に 色分けした．視標検出率が平均より低かった有効視野狭窄群 E1，E5，E11，E13，E14，E15 の傾向は，左右 $-15^{\circ}$ から $15^{\circ}$ までは視標を認識できているが，それより広い範囲においてその検出率が下がる傾向にある．また，全 体の傾向として, 中央下（奥行き距離 $0.5 \mathrm{~m}$ ）に出現した視標に対して検出率の高い領域があり，運転時の視野範 囲が中央手前付近に偏在しており，高齢運転者が若年運転者に比心゙，前方でも車に近いところを見る傾向を示し た研究 ${ }^{(14)}$ と同様の結果を示寸ものとなった. 次に, 分割的注意能力の測定結果を図 10 に示す. 本結果は, 周辺視 課題, 二重課題の二つの課題の違いにより, 認識できた周辺視刺激に対するボタンの反応時間により評価してい る．要するに，知覚はできているが処理負荷の違いによる結果を示したものである．そこで，測定を行った全参 加者の周辺視課題と二重課題の課題間における反応時間について $\mathrm{t}$ 検定を行ったところ，3 名について有意差が 認められた（p<0.01）。但し，本実験において，DS 酔いや実験の不都合によりデータが採取できなかった実験参 加者の結果は除いている.

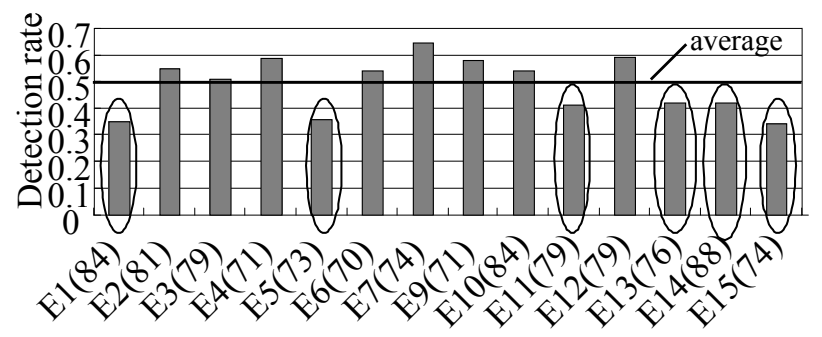

Fig. 8 Result of useful field of view test on DS

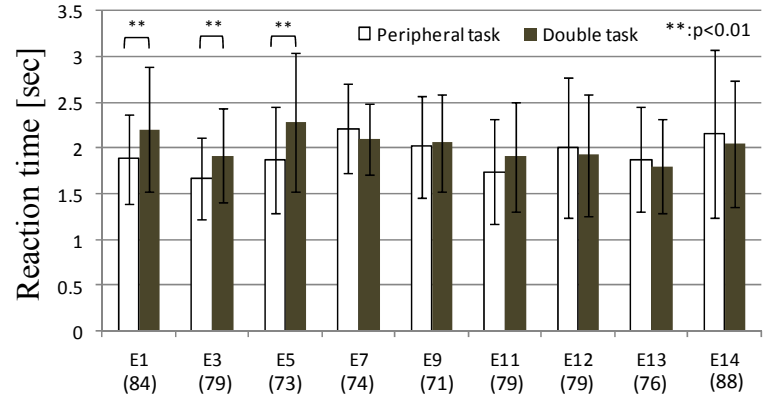

Fig. 10 Result of divided attention test

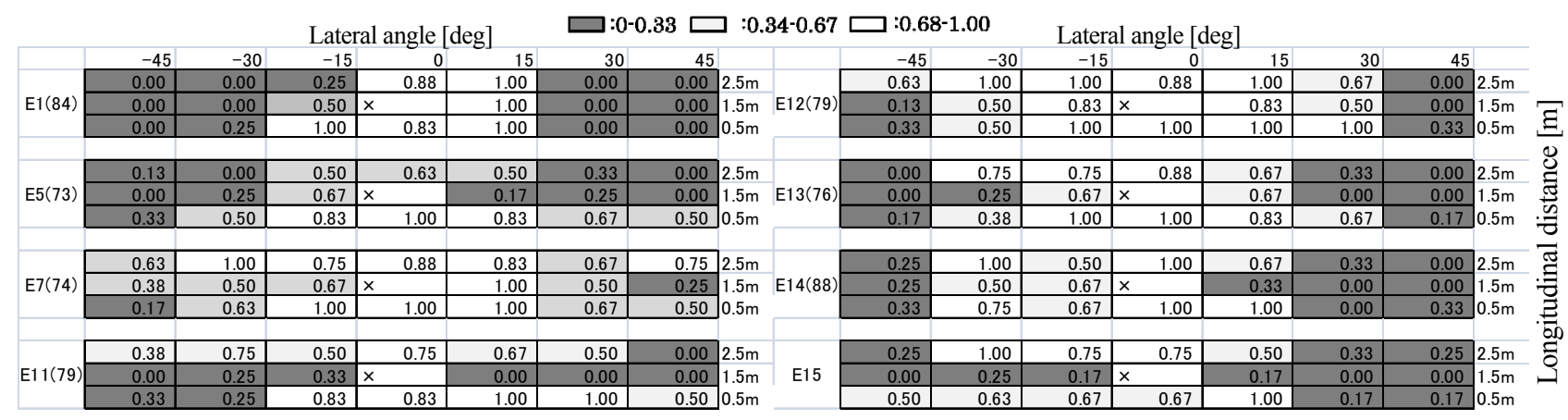

Fig. 9 Detection range of each subject with narrowed useful field of view

\section{$5 \cdot 2$ リスク知覚特性把握実験の結果}

運転時の確認行動，減速行動を分析するため，無信号交差点における運転者による視線位置と速度調整の違い について, E5 と E12の一例を図 11 示す. 同一の無信号交差点において, E12 は交差点手前 $100 \mathrm{~m}$ 付近で減速し, また，交差点手前 $30 \mathrm{~m}$ 付近で左右を確認している。一方の $\mathrm{E} 5$ は高い速度を維持したまま交差点に進入し，確認 
も行っていない.このような確認行動と操作行動の違いを基に，全試行における各参加者の確認行動と減速行動 の回数を無信号交差点通過時，一時停止交差点通過時の全試行数に対する割合として表 5 に示す.
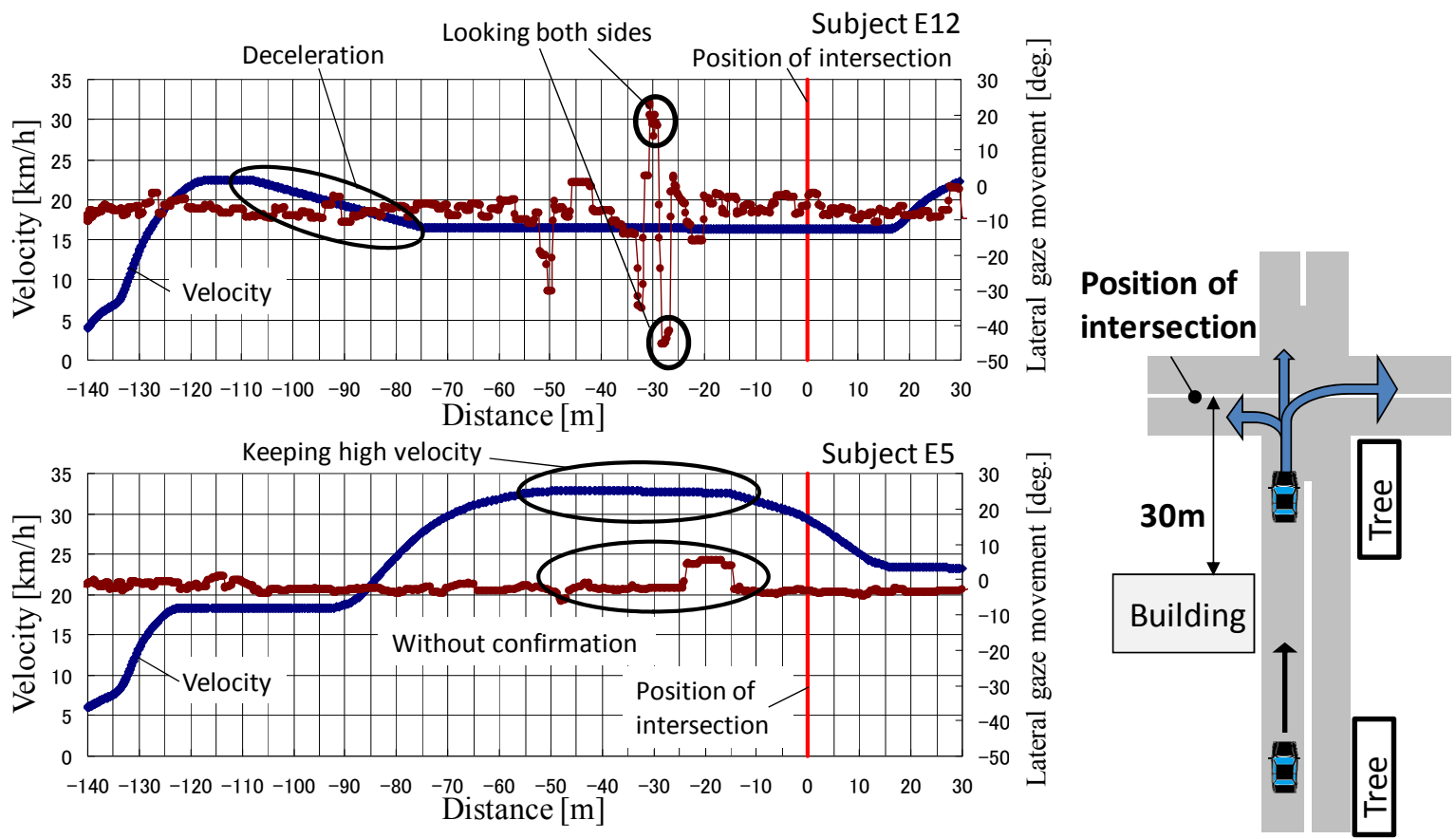

Fig. 11 Lateral gaze movement and velocity of E5 and E12 before arriving at the intersection

Table 5 Experimental result of risk perception

\begin{tabular}{|c|c|c|c|c|c|c|c|c|c|c|}
\hline & & E1 & E3 & E5 & E7 & E9 & E11 & E12 & E13 & E14 \\
\hline \multirow{2}{*}{ 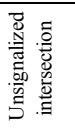 } & $\begin{array}{c}\text { Decelation or } \\
\text { keeping low } \\
\text { velocity } \\
\end{array}$ & 0.67 & 0.67 & 0.67 & 0.00 & 0.67 & 0.67 & 1.00 & 0.50 & 1.00 \\
\hline & Confirmation & 0.00 & 0.00 & 0.00 & 0.00 & 0.00 & 0.17 & 0.83 & 0.00 & 0.50 \\
\hline 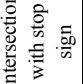 & Confirmation & 0.31 & 0.58 & 0.25 & 0.71 & 0.42 & 0.29 & 0.92 & 0.96 & 0.13 \\
\hline
\end{tabular}

Table 6 Classification based on cognitive features

\begin{tabular}{|c|c|c|c|c|c|}
\hline & \multicolumn{4}{|c|}{ Risk perception } \\
\hline & & \multicolumn{2}{|c|}{ Unsignalized intersection } & \multirow{2}{*}{$\begin{array}{c}\text { Intersection with stop sign } \\
\text { No confirmation }\end{array}$} & \multirow[b]{2}{*}{ Good } \\
\hline & & $\begin{array}{l}\text { No decelaration or } \\
\text { keeping high velocity }\end{array}$ & No confirmation & & \\
\hline \multirow{3}{*}{ 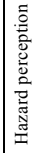 } & $\begin{array}{c}\text { Low devided } \\
\text { attention ability }\end{array}$ & - & E1 E3 E5 & E1 E5 & - \\
\hline & $\begin{array}{c}\text { Narrowed useful } \\
\text { field of view }\end{array}$ & - & E1 E5 E11 E13 & E1 E5 E14 & - \\
\hline & Good & E7 & E9 & E9 & E12 \\
\hline
\end{tabular}

\section{$5 \cdot 3$ 認知特性の分類と考察}

実験参加者を対象に実施する運転行動と認知特性の関連性を検討するため, 今回把握したハザード知覚特性, リスク知覚特性のデータをもとに，両認知特性による分類を試みた，分類にあたり，各実験結果について分類の 基準を定める必要があるが, 本研究では 14 名という限られた参加者の中で認知特性と運転行動の関係を検討する ため, 参加者内の相対的な特性の違いに基づき分類を行う.

\section{・有効視野特性による分類}

参加者全体を有効視野特性の異なる $2 つ の$ 群に分けて運転行動との関係の議論を進めるため, 全体の平均值を 基準に，これを下回った参加者を有効視野低群として分類した.

\section{· 分割的注意特性による分類}

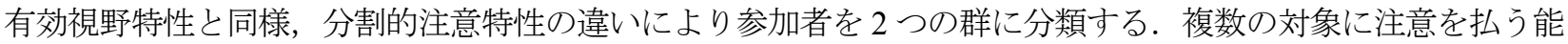
力の低下の程度の違いを分類基準とするため, 参加者間の二重課題に対する反応時間の違いではなく, 周辺視課 題と二重課題における反応時間に有意な差が認められた 3 名について分割的注意能力低群として分類した.

\section{・リスク知覚特性による分類}

限られた試行数，限られた属性をもつ参加者の中でリスク知覚特性による分類を行うため，潜在的ハザードが 存在するシーンにおいて減速行動, 確認行動が全試行通じて 1 度も見られなかった参加者について, リスク知覚 低下群として分類した。 


\section{·認知特性のタイプ分類}

認知特性をハザード知覚とリスク知覚の 2 つ独立した特性に分けて捉えたことで，表 6 に示すような実験参 加者を認知特性の視点から次の 4 つのタイプに分類する事ができる.

- 両特性共に良好なタイプ

- 八ザード知覚特性のみ劣るタイプ

- リスク知覚特性のみ劣るタイプ

- 両特性共に劣るタイプ

本分類の特徵は，運転における認知の特性を従来研究で扱われてきた有効視野や分割的注意能力といった身体 的な特性に加え，各運転者がもつ経験や運転に対する意識を含む心理的要素が影響するリスク知覚の特性と組み 合わせ，運転者の認知特性として評価したことにある.

\section{6. 高齢運転者の認知特性と実車運転行動の関連性の検討}

5 章で把握した各高齢運転者の認知特性と実車における運転行動の関係を把握するため，運転行動記録実験に 協力頂いた参加者 4 名に対して，分析を行った.

\section{$6 \cdot 1$ 実験参加者の認知特性の再整理}

運転行動記録実験の実験協力者 4 名の不安全行動と彼らの認知特性の優劣の関係を検討するため, 5 章でえた データをもとに，指標の再整理を行った，八ザード知覚能力は，運転操作と同時にコース上にランダムに出現す る視標に対し反応寸るという課題の成績から視標の検出数を取り上げ, “検出率”として評価した. またリスク知 覚能力は, 対象としたシーン全ての一時停止交差点通過の事例において, 意図的に安全確認を行った事例の占め る割合を “確認率”とした．これらの評価指標をそれぞれ縦軸，横軸にとり，それぞれの軸の交点がえられたデ 一タの平均值を 0.5 として補正すると図 12 のように実験参加者の認知特性が整理でき, 各実験参加者の位置づけ が明確になる. ハザード知覚能力, リスク知覚能力が共に高いのが E3, E12, 八ザード知覚能力が低くリスク知 覚能力が高いのが E13，両能力共に低いのが E5 という整理ができる. この認知特性と表 2 に示寸実車運転時の急 減速行動をとった事例結果を比較すると，DRにより採取した結果では，E3，E12 とも，ハザード知覚，リスク知 覚に影響する要因で急減速を行った事例はなく, E13 は八ザード知覚に影響する要因で急減速行動を行っており, E5 は八ザード知覚に影響する要因やリスク知覚に影響する要因で急減速行動を行っている.よって, 各実験協力 者の認知特性が DR で採取した急減速行動の要因と関連性があることが示された.

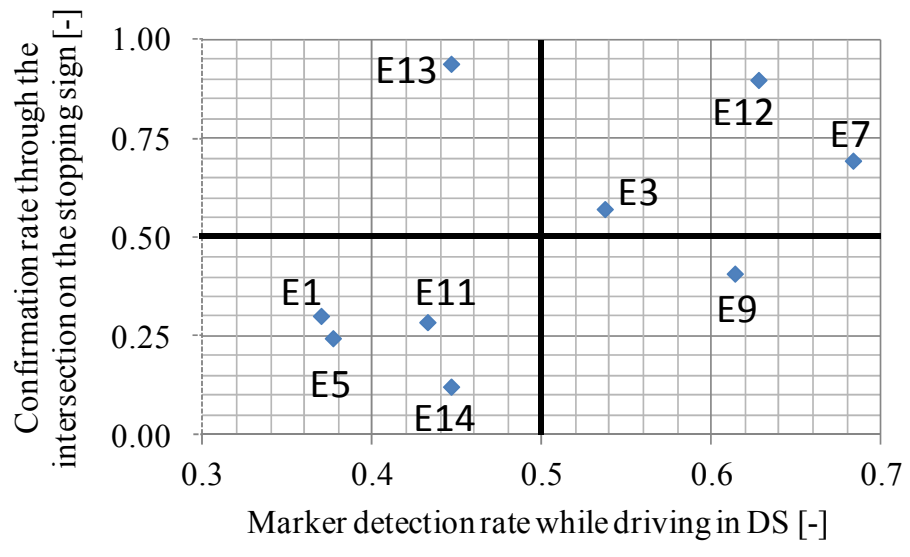

Fig.12 Cognitive features of each subject

\section{$6 \cdot 2$ 右折シーンにおける不安全行動の発生要因と認知特性の関連性}

運転には多種多様のシーンが存在する. 6 ・1 節で急減速行動の要因と認知特性の劣化に関連性が見られた実験 協力者 E5, E13 について, 高齢運転者の事故が多いとされる(9)右折シーンにおける不安全行動について検討を行 
った.ここでの狙いは，認知特性の劣化が右折時の不安全行動に表れるかどうかを検討することにより，認知特 性の分類の妥当性を検討することである.

DR より得られた急減速時の運転行動データから, E5 が信号交差点で右折する場面を考える. 対向右折車と後 続の直進車の間に割り込み，右折後，前車である対向左折車が急減速したため，自車も急に減速した．交差点に 侵入してから急ブレーキをかけるまでの過程を 4 つフェーズに分けて説明する. フェーズ 1〜4 の映像データ及 び交差点の状況の模式図を図 13 に示す.この事例は, 衝突事故に繋がりうる後続対向車に対寸る優先通行妨害と 対向左折車との追突の可能性という 2 つ不安全行動を含んでいる. フェーズ 3 において後続対向車を確認して いる様子が見られることから，E5 は後続対向車の存在には気づいていると考えられる，そのことを踏まえ，1つ 目の不安全行動の発生過程を図 2 の概念図に基づいて考えると, 自車の右折に際し E5 はハザードとして後続対 向車を認識していたが，リスク知覚過程で後続対向車のもつリスクを低く評価したため，右折を開始したと考え られる. 次に対向左折車への衝突につながる不安全行動の発生過程を考えると，後続対向車に注意を奪われた結 果，八ザード知覚過程で対向左折車の動静に注意を向けることが出来ず，その結果急ブレーキに至ったと考えら れる. よってこの事例は, ハザード知覚能力, リスク知覚能力が共に低下した結果起こった不安全行動と考えら れ，八ザード知覚能力, リスク知覚能力が共に低下しているという E5 の認知特性の傾向と関連性がある.
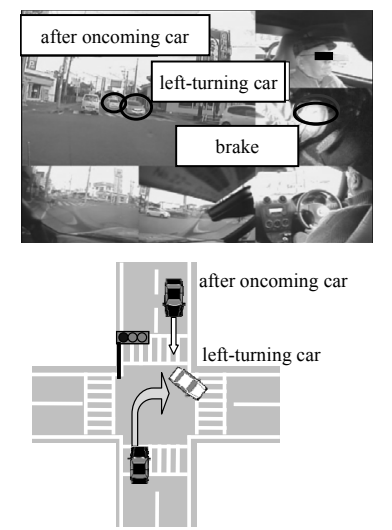

Phase 1
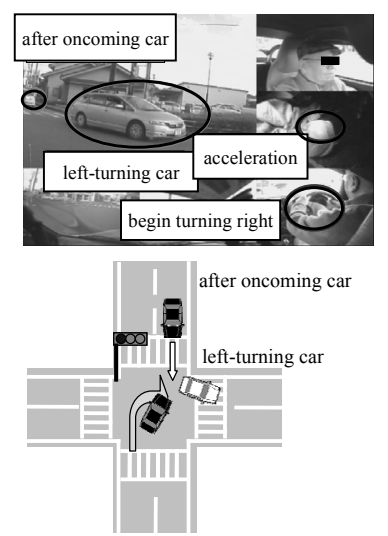

Phase 2
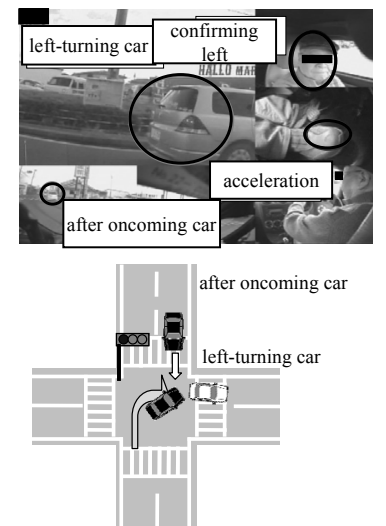

Phase 3
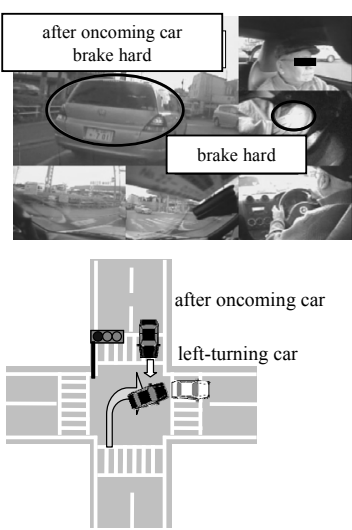

Phase 4

Fig. 13 Video image and intersection condition of each phase in turn right situation (subject E5)

同様に，E13 が無信号交差点を右折する場面を考える. 交差点進入から歩行横断者に気づきブレーキペダルを 踏むまでの過程を 4 フェーズにわけて説明する.フェーズ 1 から 4 までの映像データを図 14 に示す.この事例は, 対向車と横断歩行者という複数のハザードに対し分割的注意を求められる場面である. 注意すべき対象が複数存 在する場面で右折行動を続けた結果，横断歩行者に気づくのが遅れ，急減速に至ったと考えられる．この不安全 行動はE13 の認知特性であるハザード知覚能力の低下の傾向とも一致する.
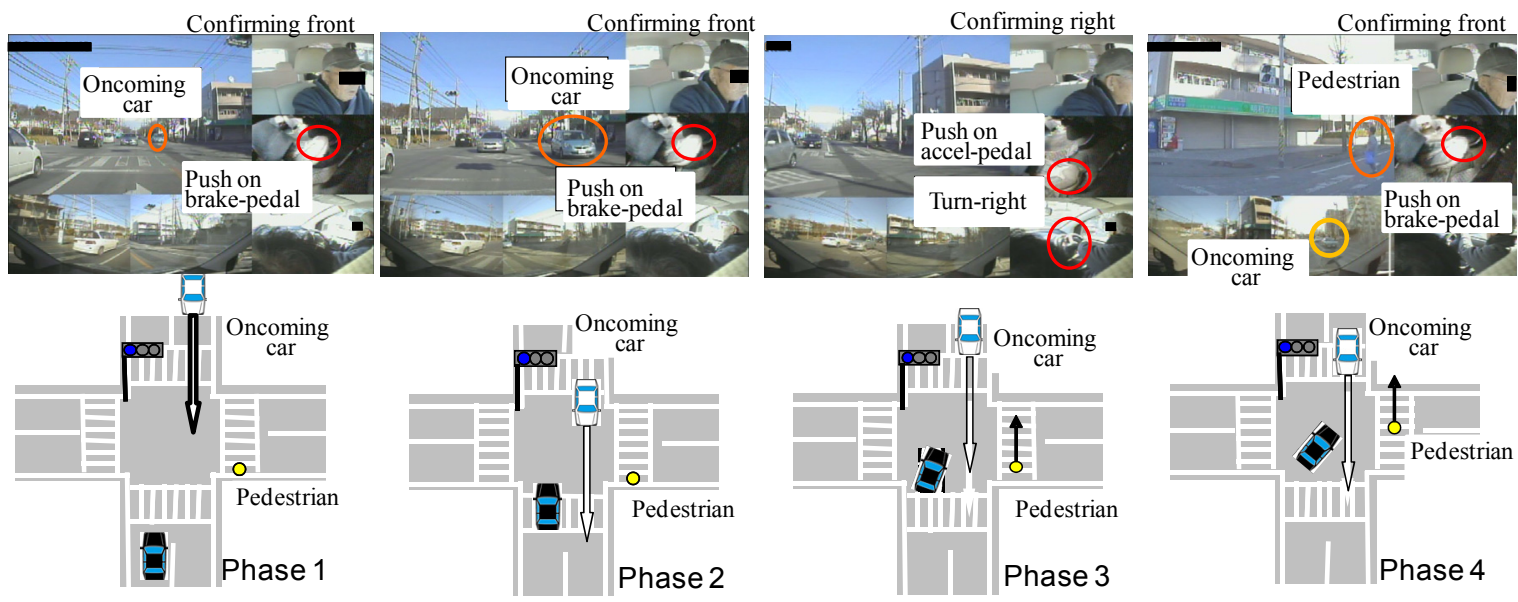

Fig. 14 Video image and intersection condition of each phase in turn right situation (subject E13) 


\section{7. まとめ}

高齢者の認知能力低下に起因寸る特性をハザード知覚とリスク知覚の二つの特性に分けて捉え，不安全な運転 行動の発生過程としてそれぞれの特性に着目した. そこで, 14 名の高齢者に対して各特性を把握し, ドライブレ コーダにより計測した日常生活における運転行動記録とその特性を比較した結果，以下に示寸知見がえられた.

・高齢運転者の認知能力をハザード知覚, リスク知覚の両観点から分類する評価指標を提案した.

- 提案した評価指標に基づき, 高齢運転者の認知特性の分類を行った.

- 提案した認知特性に基づく評価指標による分類と運転行動過程を用いて, 高齢運転者の認知特性に影響する 不安全行動の発生過程を説明できる可能性を示した.

今後は, 本研究で得られた評価指標の妥当性と不安全行動の関連性に関する統計的な議論ができる様，実験参 加者の人数を増やし，交通環境の属性に対する高齢運転者の認知特性の影響に展開する予定である.

\section{謝 辞}

本研究を進めるにあたり, 柏市老人クラブ連合会の皆様に実験の協力を頂いた. 心よりお礼申し上げる. また, 本研究は平成 22 年度鉄道運輸機構より研究助成を受けて行われた.

\section{文献}

（1）警察庁，平成 20 年中の交通事故発生状況(2009)，pp. 21，警察庁交通局.

(2) Cynthia Owsley, "Vision and driving in the elderly", Investigative Ophthalmology \& Visual Science, Vol.34, No. 11(1993), pp.3110-3123.

(3) Renee S.Myers, Karlene Ball, Thomas D.Kalina, David L.Roth and Kathryn T.Goode, "Relation of useful field of view and other screening tests to on-road driving performance", Perceptual and Motor Skills, Vol. 91, No. 1(2000), pp.279-290.

(4) Laura A. Cushman, "Cognitive Capacity and Concurrent Driving Performance in Older Drivers", IATSS Research, Vol. 20, No. 1(1996), pp.38-45.

(5) 小竹元基，都築巧真，鎌田実，“高齢者の運転評価ツールを目指した知覚・認知特性の検討”，日本機械学会第 14 回 交通物流部門大会講演論文集，No.05-52(2005)，pp.377-380.

(6) 小竹元基, 細川崇, 宇治信孝, 鎌田実, “高齢運転者の運転特性とその背景要因に関する研究（第 1 報 : 高齢者の生 活・身体特性と運転特性の関連性)”，日本機械学会論文集 C 編，Vol.71，No.709 (2005)，pp.124-131

(7) 細川崇, 小竹元基, 鎌田実, 金森等, 不破本義孝, 梅村祥之, “高齢運転者の日常運転行動記録を基にした右折時不 安全行動の把握とその評価”，自動車技術会論文集，Vol.39，No.4(2008), pp.131-146

(8) 小竹元基, 鎌田実, 金森等, “一時停止交差点進入時における高齢運転者のための情報提示による認知支援システム”, 自動車技術会論文集，Vol.40， No.6(2009)，pp.1605-1610.

(9) 交通事故総合分析センター, “イタルダ・インフォメーション”, No. 68(2007), pp. 8-10.

(10) 蓮花一己, “運転時のリスクテイキング行動の心理的過程とリスク回避行動へのアプローチ”, 国際交通安全学会誌 Vol.26, No.1(2000), pp. 12-22.

(11) 小川和久, 蓮花一己, 長山泰久, “ハザード知覚の構造と機能に関する実証的研究”, 応用心理学研究, No.18(1993), pp.37-54.

(12) 稲垣敏之, “これからの運転支援システムに求められる視点”, 自動車技術会学術講演会前刷集, No.9-10(2010), pp.1-4.

（13）木村賢治，片山孝司，荻谷光晴，西村聡生，川島隆太，筒井健一郎，塩入諭，“運転者の有効視野の向上に関する 研究”，自動車技術会学術講演会前刷集，No.120-09(2009), pp.21-24.

(14) 福田亮子, “高齢ドライバーの視覚情報受容と運転行動”，人間工学，Vol.45，No. 3(2009), pp.183-188. 